\title{
Cattle teats' milk quality and prevalence of mastitis by electronic mastitis detector in Burkina Faso
}

\begin{abstract}
Two experiments were carried to run milk samples for composition, bacteria count and prevalence of mastitis on farm. The first experiment included 24 lactating cows from two farms during August and September 2012. In total, 192 teats raw milk samples of $30 \mathrm{~mL}$ were collected during morning and evening milking. The second experiment included 30 lactating cows from three farms (November to December 2015 and January to March 2016). In total, 120 teat milks were tested with Electronic Mastitis Detector (4X4QMAST) and strip milk samples were collected. Milk was run for composition by infrared method (Dairy milk analyzer, Miris AB Sweden 2001) and milk pH using pH-meter. DeLaval Cell Counter by fluorescence was used to count somatic cells in milk. The gelose Baird Parker and geloseLactis of Cristal Violet and Neutral Red were used to grow Staphylococcus aureus and Escherichia coli, respectively. The plate count agar was also used to grow the total bacteria. The data of the first and the second experiment were subjected to analysis of variance (ANOVA) using Minitab 15 and XLSTAT 6.1 .9 , respectively. The results showed that milk fat, protein and lactose contents were different from teat to teat and the average was $3.39 \%$ fat, $3.37 \%$ protein and $4.32 \%$ lactose. Bacteria count was also different from teat to teat. The average bacteria count of Staphylococcus aureus was $4 * 103 \mathrm{cfu} / \mathrm{mL}$ and of Escherichia coli was $103 \mathrm{cfu} / \mathrm{mL}$. The somatic cells of saleable milk were assessed and the somatic cells count (SCC) average was between 4.94 and 6.18 cells $/ \mathrm{mL}\left(\log _{10} \mathrm{SCC}\right)$. Very low prevalence of mastitis was found (12.5\%) and strip milk fat and protein contents were also lower. In conclusion, the lower prevalence of mastitis was due to limited number of animals and the uneven milking routine gave very low strip milk contents with S. aureus and E. coli found in raw milk strongly indicated hygiene problem and contamination on farm.
\end{abstract}

Keywords: farm, milking, teats milk, bacteria count, mastitis, prevalence
Volume 7 Issue I - 2018

\author{
Millogo Vinsoun,' Kéré Michel,' Sissao \\ Mariétou,' Sanou Drissa,' Ouédraogo \\ Georges Anicet' \\ 'Department of Animal Production, Institute of Rural \\ Development, University of Nazi Boni, Burkina Faso
}

Correspondence: Vinsoun Millogo, Institute of Rural Development, University of Nazi Boni, 0I P.O. Box 1091, BoboDioulasso 0I, Burkina Faso, Tel +22670228995. Email paravins@yahoo.fr

Received: October 30, 2017 | Published: January 17, 2018
Abbreviation: S. Aureus, Staphylococcus aureus; E Coli, Escherichia coli; CFU, colony forming unit; $\log _{10}$, logarithm base 10

\section{Introduction}

Mastitis is a dairy farm disease which causes important loss for dairy industry. Mastitis control is permanent challenge for dairy farm. ${ }^{1}$ Milk loss link to mastitis was assessed to reach $17 \%$ of world milk production. ${ }^{1}$ In Burkina Faso, this loss is not assessed and remains unknown area. It is well known that the most spread mastitis is subclinical which has considerable impact on farm and decrease milk yield and quality. ${ }^{2,3}$ It is therefore urgent to assess mastitis on dairy farm related to milking in Burkina Faso because the presence of mastitis is linked directly to presence of bacteria. Clinical mastitis could be detected and treated by farmers. However, subclinical mastitis is silent and affects milk production without any suspicion from farmers. Today, several tests could be used to reveal presence of mastitis but there are not all affordable to farmers. The well-known method is California mastitis test (CMT) which could be used by farmers to discard mastitis cows before milking. The advanced method like somatic cells counter is used to count number of somatic cells in saleable milk. ${ }^{4}$ It is also possible to check efficiency of milking by run fat content of strip milk. The strip milk shows how farmer supposes to end up the milking process.

In Burkina Faso, one big challenge is high bacteria count in raw milk. ${ }^{5}$ When teat canal is cleaned before milking, the total bacteria count is lower and immediately increases when milk is being put in milking bucket. ${ }^{5}$ The common bacteria species isolated in raw milk are Streptococcus uberis, Escherichia coli, Staphylococcus aureus ${ }^{6-8}$ which shows important of teat control before milking. There is still a discussion regarding at which level of cells count mastitis occurs. Twenty years ago research found 200,000 cellules/mL but recently the level decreases to 100,000 cellules/ $\mathrm{mL}^{1,9-10}$ and even today the discussion is around 50,000 cells $/ \mathrm{mL}$. Now, the debate is not the number of cells but the type of bacteria in milk which could be very dangerous. ${ }^{11}$ Regarding the mammary gland status of cattle, one quarter could be affected amongst the four since they are independent. ${ }^{1,5}$ This explains why it is also important to check each teat before milking and if possible milk from each quarter and that avoid mixing wrong milk to good one. The current research paper is a summary of two separate studies carried out in the same area from small dairy farms at the peri-urban area of Bobo-Dioulasso, Burkina Faso. The aim of the studies was to assess bacteria count of two species from quarter milk and also determine prevalence of mastitis on farm using electronic mastitis detector (4X4QMAST) related to milking efficiency.

\section{Materials and methods}

Two compensatory studies were performed to assess milk quality. The first experiment was carried according to the production schedule to assess quarter milk quality of dairy cattle during the rainy season from August to September 2012 at two small dairy farms. The second experiment was carried out at three other small dairy farms in order 
to assess mastitis prevalence from November to December 2015 and from January to March 2016.

\section{Dairy farms and farming system}

The farms were located in the peri-urban area of BoboDioulasso,Western Burkina Faso. Dairy cattle were mainly local breeds called Zebu (Bos indicus) and crossbred cows (ZebuxHolstein, ZebuxMontbeliard, ZebuxBrune des Alpes, Zebu Gir). Natural reproduction and artificial insemination were practiced by farmers. The housing system for cattle was dairy barn built as house. The feeding system was based on natural pasture and supplementation any time. Supplementation feed were cotton seed cake, dry forage, maize residues, rice and maize bran. Farmers practiced veterinary treatment roughly. Twice daily hand milking was practiced during morning (06h00) and evening (17h00) and calf was used for milk let down. Individual milking equipment was assigned to each cow. Milk person was the one who was responsible to keep animals on pasture. Milk was collected in 05 liters plastic can. Milk produced was mainly sold to local dairy processing unit.

\section{Milk sampling}

The first experiment included twenty (24) lactating cows and milk samples were taken during milking and at the end. Milk let down started with calf stimulation which took 30 to 60 seconds and a milk bucket was assigned to individual cow. On the course of milking, milk sample of $30 \mathrm{~mL}$ was collected in test tube. Milk sample was taken after three and half minutes during milking time. Suckling time consumed by calf was not evaluated. Milk sample was collected from individual quarter and sampling for all four quarters which took almost one minute. The sampling was done once a week and 192 quarters' milk samples were collected during milking and 08 bucket milk samples divided into 08 aliquots for milk composition and 08 aliquots for determination somatic cells count. Only the saleable milk was run for cells count.

Each cow had four teats and all four were defined as follow: right fronter teat (RFT), left fronter teat (LFT), right rear teat (RBT) and left rear teat (LBT). Sampling took place morning (M) at $6 \mathrm{~h} 00$ and evening (E) at $17 \mathrm{~h} 00$ for all cows. Milk samples were put in ice box with +10 to $+12^{\circ} \mathrm{C}$ as transportation temperature. After collecting milk samples from individual quarter, another sample of $30 \mathrm{~mL}$ was collected from bucket milk at the end of the whole milking process. This sample was divided into $15 \mathrm{~mL}$ each. One aliquot was run for somatic cell count (SCC) and milk composition and the second one for bacteria count. Sampling took once a week and along two months. Milk sample transportation time to the laboratory was around 30minutes where milk samples were stored at $+4^{\circ} \mathrm{C}$ in the refrigerator before determination of milk composition the same day. The second experiment included thirty (30) lactating cows from three different farms with 15,8 and 7 cows at each farm respectively. The farm location was Kimidougou, Farako-Ba and City of Belle-ville in Bobo-Dioulasso. The milking routine was similar as done in the first experiment. The strip milk samples were collected at the end of milking and run for only for fat and protein contents.

\section{Determination of milk pH and milk composition}

Milk $\mathrm{pH}$ was determined for each sample using $\mathrm{pH}$-meter $(370 \mathrm{pH}$ Meter Jenway, European Union). Density, milk fat, protein, lactose contents were determined by infrared spectroscopy using Dairy Milk Analyzer (2001, Miris AB, Sweden). Somatic cells were measured by fluorescence using De Laval Cell Counter (Tumba, Sweden). Somatic cells count was number of cells $/ \mathrm{mL}$ of milk.

\section{Microbiological analysis of milk samples}

Bacteria count was determined through selective culture agar to grow Escherichia coli and Staphylococcus aureus. In the text, please read Escherichia coli as E.coli and Staphylococcus aureus as S. Aureus. Lactose purple crystal agar and neutral red (Liofilchem, ref 610058, Italy) was used for counting E.coli and Baird Parker agar (Liofilchem, ref 610004, ISO 6888, Italy) was used for counting S. aureus. Sixty grams of Baird Parker powder was diluted in 01 liter of distilled water and then the culture medium for $\mathrm{S}$. aureus was diluted with distilled water and sterilized in autoclave at $+121.11^{\circ} \mathrm{C}$ during 15 minutes. $40.5 \mathrm{~g}$ of lactose purple crystal agar and neutral red was diluted in 01 liter of distilled water. The culture medium for E.coli was diluted but not heated up in autoclave. A slow cooling was applied on culture medium. Sterilize knead boxes were used for bacteria counting. One (01) milliliter $(\mathrm{mL})$ of milk sample was mixed with each specific culture medium in identified sterilize knead box. The culture medium and milk were homogenized before bacterial plating. Bacterium incubator was Incucell, MMM Med center Einrichtungen (GmbH, MMM-Group, German). Incubation for all kneads boxes for E.coli took 24 hours at $+30^{\circ} \mathrm{C}$ and 48 hours at $+35^{\circ} \mathrm{C}$ for S. aureus. After the respective times and temperatures, all knead boxes were withdrawn from the incubators and the bacteria counting started using color and size of bacteria colony. The counting was done by checking the back side of the knead box without opening it.

\section{Determination of mastitis prevalence by electronic mastitis detector}

Electronic Mastitis Detector is a reading device with stray of four small pots (sensors). The reading screen of liquid-crystal (LCD) shows the results after measurements of all four teats. The case is prolonged by sleeve with command button. There is a battery of $9 \mathrm{~V}$ model 6F22, 6LR61 and 1604E (Figure 1).

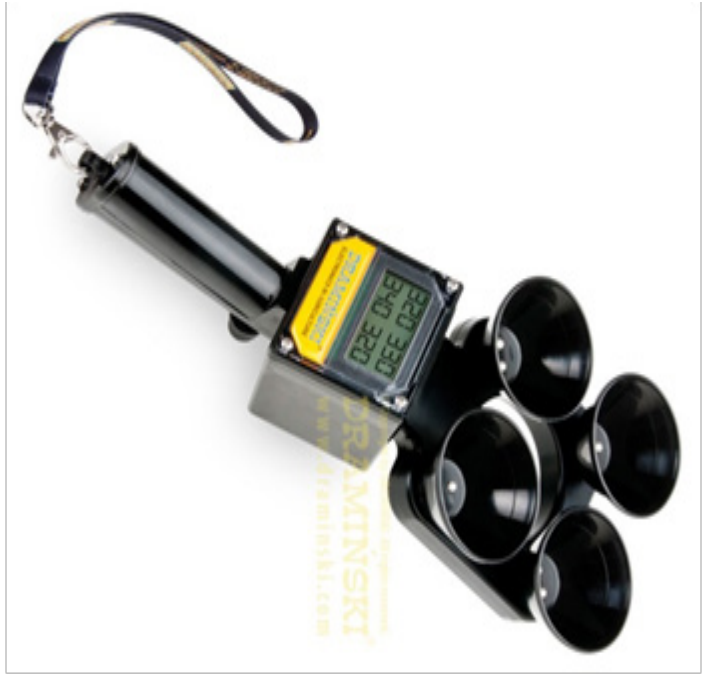

Figure I Electronic mastitis detector (4X4QMAST $囚$ ).

The use of the instrument recommends a preliminary test when the pots are empty. When you press the command button, the screen displays 4 groups of horizontal bars (dash) which show that the instrument is running very well and then ready to be used. The second 
step was measurement. The pots are placed below the lactating cows according to right fronter teat (RFT), left fronter teat (LFT), right rear teat (RBT) and left rear teat (LBT). The first throw milk was put in each pot until the maximum volume was reached (about $1 \mathrm{~cm}$ high). Milk from each quarter was put in each pot and when the command button was pressed, the process took 3 seconds by showing three steps in the screen as presented below. After measurement milk should be removed very quickly from pots.

\begin{tabular}{|l|l|}
\hline 33 \\
33 \\
\hline
\end{tabular}

\begin{tabular}{|l|}
22 \\
22
\end{tabular}

\begin{tabular}{ll|}
11 \\
11
\end{tabular}

The screen display results for each quarter as shown below.

\begin{tabular}{|l|}
370380 \\
380380
\end{tabular}

The instrument is calibrated as minimum value of 10 and maximum of 990units. If the results are below 10 or over 990units, the screen displays horizontal bars to show that it is not working. When the screen displays the result, press again the command button to detect the affected teat which shows higher value as presented below.

\begin{tabular}{|ll|}
\hline 10 & 0 \\
0 & 0
\end{tabular}

At the end of each measure the pots are cleaned with distilled water. The data are deleted by pressing the command button after measurement and notes. Then, the next measurement can be done.

\section{Statistical analysis}

The data of the first experiment were subjected to analysis of variance (ANOVA). All variables were checked to normal distribution nusing Minitab version 15 (Minitab Inc, 2009). Cows and teats were included as factors in the statistical method. Variables were milk $\mathrm{pH}$, density, milk fat, protein, lactose contents. Data on bacteria count was subjected to logarithm transformation base 10. Means were compared using Tukey's test and considered to be different at $p<0.05$. The data of the second experiment was subjected to ANOVA using XLSTAT 6.1.9. Means were compared using student test and considered to be different at $\mathrm{p}<0.05$. Mastitis prevalence was calculated according to number of affected cows/total risk population of cows at the farm* 100 .

\section{Results}

The Table 1 showed similar fat, protein and lactose contents for all quarters. There was any difference between quarters for fat, protein and lactose contents. The average of fat and protein contents was around 3\%. Milks from rearer teats showed higher fat content than milk from fronter teats. Milk density also showed similar value for all quarters and the average was 1.03. Milk pH showed the same trend for all quarters. The results showed very low saleable milk yield collected by farmers. The average was between 1.20 and 2.55 liters for each cow a day with little difference between cows. The somatic cells of saleable milk were assessed and the somatic cells count (SCC) average was between 4.94 and $6.18 \mathrm{cells} / \mathrm{mL}\left(\log _{10} \mathrm{SCC}\right)$.

The Total bacteria flora (TBF) was similar for all four teats' milk without any difference $(\mathrm{p}>0.05)$ (Table 2$)$. All milks samples showed presence of $\mathrm{S}$. aureus. The frontier teats showed higher bacteria count in milk for S. aureus than rearer teats without any difference. The bacteria count for E.coli was higher in milks from rearer teats than fronter teats'milk and there was a difference $(p<0.05)$. Several milks samples from fronter and rearer teats did not show any colony of $\mathrm{E}$. coli and the average of 96 teams are shown in Table 1 during two months. The electric mastitis detector was able to show a presence of subclinical mastitis in a farm located in the city (Belle-ville) which means that at each measurement time, at least one cow was affected during the experimental time. Mastitis prevalence was $12.5 \%$ during each measurement time (Table 3 ). The electric resistivity for all milks was higher than 250units but close to that number. However, the strong suspicious was stated and it was difficult to conclude presence of mastitis. The results showed presence at least of one affected cow during time of measurement (Table 3). Milk from farm A where subclinical mastitis was detected revealed low fat content compared to farms B and C. Fat and protein contents of the strip milk were quite low (Table 4). Any difference was mentioned regarding fat and protein contents, milk electric resistivity and all four teats showed similar values.

Table I Average of teats' milk composition

\begin{tabular}{llllll}
\hline Quarters & Fat (\%) & Protein (\%) & Lactose (\%) & Density & Ph \\
\hline Right front & $3.0 \pm 0.40^{\mathrm{a}}$ & $3.3 \pm 0.08^{\mathrm{a}}$ & $4.2 \pm 0.23^{\mathrm{a}}$ & $1.03 \pm 0.00^{\mathrm{a}}$ & $6.6 \pm 0.06^{\mathrm{a}}$ \\
Left front & $3.3 \pm 0.4^{\mathrm{a}}$ & $3.3 \pm 0.08^{\mathrm{a}}$ & $4.3 \pm 0.20^{\mathrm{a}}$ & $1.03 \pm 0.00^{\mathrm{a}}$ & $6.2 \pm 0.06^{\mathrm{a}}$ \\
Right rear & $3.4 \pm 0.3^{\mathrm{a}}$ & $3.3 \pm 0.08^{\mathrm{a}}$ & $4.3 \pm 0.16^{\mathrm{a}}$ & $1.029 \pm 0.00^{\mathrm{a}}$ & $6.6 \pm 0.06^{\mathrm{a}}$ \\
Leftrear & $3.7 \pm 0.4^{\mathrm{a}}$ & $3.3 \pm 0.09^{\mathrm{a}}$ & $4.3 \pm 0.2^{\mathrm{a}}$ & $1.028 \pm 0.00^{\mathrm{a}}$ & $6.5 \pm 0.06^{\mathrm{a}}$ \\
\hline
\end{tabular}

LSMean 
Table 2 Average of bacteria count in teat's milk

\begin{tabular}{llll}
\hline Quarters & $\begin{array}{l}\log _{10} \text { S.Aureus } \\
(\mathbf{c f u} / \mathbf{m l})\end{array}$ & $\begin{array}{l}\log _{10} \text { E. Coli } \\
(\mathbf{c f u} / \mathrm{ml})\end{array}$ & $\begin{array}{l}\log _{10} \text { TBF } \\
(\mathbf{c f u} / \mathrm{ml})\end{array}$ \\
\hline Right front teat & $4.16 \pm 0.31^{\mathrm{a}}$ & $1.18 \pm 0.00^{\mathrm{a}}$ & $4.50 \pm 0.30^{\mathrm{a}}$ \\
Left front teat & $4.17 \pm 0.36^{\mathrm{a}}$ & $1.4 \pm 0.00^{\mathrm{a}}$ & $4.58 \pm 0.22^{\mathrm{a}}$ \\
Right rear teat & $3.87 \pm 0.27^{\mathrm{a}}$ & $3.17 \pm 008^{\mathrm{b}}$ & $4.48 \pm 0.30^{\mathrm{a}}$ \\
Left rear teat & $3.93 \pm 0.30^{\mathrm{a}}$ & $3.4 \pm 0.00^{\mathrm{b}}$ & $4.42 \pm 0.22^{\mathrm{a}}$ \\
\hline
\end{tabular}

TBF, total bacteria floras

LS Means in the same row with different superscripts ${ }^{a, b}$ and $c$ are statistically significant different at $\mathrm{P}<0.05$

Table 3 Electric resistivity of raw milk and prevalence of mastitis on dairy farms

\begin{tabular}{lllll}
\hline Farms & $\begin{array}{l}\text { Lactating } \\
\text { Cows }\end{array}$ & $\begin{array}{l}\text { Milk Electric } \\
\text { Resistivity }\end{array}$ & $\begin{array}{l}\text { Affected } \\
\text { Cows }\end{array}$ & $\begin{array}{l}\text { Prévalence } \\
\text { (\%) }\end{array}$ \\
\hline A & 15 & $390 \pm 50^{\mathrm{a}}$ & $\mathrm{I}$ & 12.5 \\
$\mathrm{~B}$ & 8 & $450 \pm 62^{\mathrm{b}}$ & 0 & 0 \\
C & 7 & $451 \pm 8 \mathrm{I}^{\mathrm{b}}$ & 0 & 0 \\
\hline
\end{tabular}

LSMeans in the same row with different superscripts ${ }^{a, b}$ and $c$ are statistically significant different at $\mathrm{P}<0.05$

Table 4 Strip milk fat and protein contents and milk electric resistivity

\begin{tabular}{llll}
\hline Teats & Fat (\%) & Protein (\%) & Electric Resistivity \\
\hline Right front teat & $4,72 \pm 0.9^{\mathrm{a}}$ & $3,21 \pm 0.5^{\mathrm{a}}$ & $425 \pm 93^{\mathrm{a}}$ \\
Leftrearteat & $4,82 \pm 0.6^{\mathrm{a}}$ & $3,23 \pm 0.7^{\mathrm{a}}$ & $426 \pm 78^{\mathrm{a}}$ \\
Left front teat & $4,86 \pm 0.8^{\mathrm{a}}$ & $3,25 \pm 0.9^{\mathrm{a}}$ & $439 \pm 59^{\mathrm{a}}$ \\
Right rearteat & $4,93 \pm 0.8^{\mathrm{a}}$ & $3,29 \pm 0.8^{\mathrm{a}}$ & $439 \pm 83^{\mathrm{a}}$ \\
\hline
\end{tabular}

LSMeans in the same row with different superscripts ${ }^{a, b}$ and $c$ are statistically significant different at $\mathrm{P}<0.05$

\section{Discussion}

Raw milk quality is a big concern of any dairy industry. The large dairy processing factory has in general equipments and laboratory to check raw at the reception point before accepting it for processing. In country where the dairy industry relies on the small processing units which have no equipments and tools to check quality of milk before processing, the hygiene of raw milk becomes big challenge. By doing a survey ${ }^{4}$ in the peri-urban areas of Ouagadougou (capital of Burkina Faso) and Bobo-Dioulasso (second large city), found that the small processing units had no cooling system and might process immediately. Our current results showed presence of bacteria in raw milk on farm (Table 2). When milk is contaminated on farm, it makes the processing more difficult and the dairy unit might have the reception criteria. The second question raised by our current results is teat's milk quality. Teat's milk fat and protein contents were lower to saleable milk fat and protein contents (Table 1). This is therefore in line with what is already known both in hand-milking. ${ }^{12,13}$ The sample run were half way milking samples. According to Johansson ${ }^{12}$ the proportion of milk components increases in the course of milking from onset to the end. This is the reason why farmers should empty the udder in order to have optimal composition of saleable milk for processing. Furthermore, milk fat and protein contents were different from one teat to another (Table 1) tell clearly milking routine should be standard on farm..$^{14}$ The results from the second experiment showed lower fat and protein contents for strip milk (Table 4), which explains that cows were not totally milked. Therefore, milking routine must be maintained and that will also improve teat hygiene on farm and bacteriological quality of milk and meet the processing requirements.

Raw milk is well known as nutritive food for the calf and it is widely used by human. Dairy cow can provide more milk than needed by calf. That why, long time ago, milk was collected as food for human. It is commonly accepted that milk is sterile when secreted into an uninfected udder and contamination occurs during and after milking. At the same time, milk hygiene remains continuous challenge for the dairy scientist and professionals because several studies have proved that it is very difficult to collect milk from cow without any contamination. ${ }^{15}$ Milk contamination starts at teats level. Staphylococcus aureus and Escherichia coli were all found in teat milks and the difference was significant between rear teats and front teats (Table 2). Higher E. coli in rear teat milk could be explained by hand milking technique. The milk person started with fronter teats and end with the rear teats. The average bacteria count was lower to what has been found in saleable milk in similar conditions of production. ${ }^{5}$ Somatic cells count and the electronic mastitis detector all showed presence of mastitis on dairy farms. The average cells count was 4.94 and $6.18 \mathrm{cells} / \mathrm{mL}\left(\log _{10} \mathrm{SCC}\right.$ and indicated the presence of mastitis. The Electronic Mastitis Detector (4X4QMAST) revealed $12.5 \%$ as prevalence as mastitis which is very low estimation and could mean that cows were healthy. The instrument showed presence of mastitis when the screen displays a value lower to 250units. Several teats milks showed results close to 250units which raises big suspicious of mastitis and since the number of cows was limited and we recommend to use large number of animals when using Electronic Mastitis Detector (4X4QMAST).

\section{Conclusion}

The research on dairy hygiene and mastitis is always standing up investigation since there is no definitive solution to this issue. The local milk processing professionals still need information from formal method and data from their surrounded farm in order to provide healthy and nutritive product to the fast growing citizens. The current study conducted two times and used different method highlighted prevalence of mastitis through cells count and electric resistivity. The somatic cells of saleable milk were assessed and the somatic cells count (SCC) average was between 4.94 and 6.18 cells/ $\mathrm{mL}\left(\log _{10} \mathrm{SCC}\right)$. It was concluded that uneven milking routine gave very low strip milk contents. Bacteria found in raw milk strongly indicated hygiene problem and contamination on farm which was not good for processing. Furthermore, the lower prevalence of mastitis was explained by the limited number of lactating cows in each farm.

\section{Acknowledgements}

The authors would like to acknowledge Central Council for Research and Development (CORAF/WCARD) for financial support for this research. The research was carried out under MDTF Amprolait's project (Appui à l'amélioration durable de la productivité et de la compétitivité des filières laitières bovines en Afrique de l'Ouest et du Centre). 


\section{Conflict of interest}

Author declares that there is no conflict of interest.

\section{References}

1. Forsbäck L. Bovine udder quarter milk in relation to somatic cell count. Focus on milk composition and processing properties. Doctoral Thesis; 2010:53.

2. Reneau J K. Monitoring mastitis milk quality and economic losses in ovine Mastitis. National Mastitis Council, Indianapolis; 1990. p. 326-333.

3. Elvinger F, Natzke RP. Elements of mastitis control. Large dairy herd management. Am Dairy Sci Assoc. 1992. p. 440-447.

4. Millogo V, Ouédraogo GA, Agenäs S, et al. Survey on dairy cattle milk production and milk quality problems in peri-urban areas in Burkina Faso. Afr J Agric Res. 2008;3(3):215-224.

5. Millogo V, Svennersten-Sjaunja K, Ouédraogo GA, et al. Raw milk hygiene at farms, processing units and local markets in Burkina Faso. Food Control. 2010;21(7):1070-1074.

6. Berthelot X, Fabre JM, Houffschmitt P, et al. Estimation de la fréquence des germes responsables de mammites chez la vache laitière en France. Renc Rech Ruminants. 1997;4:283.

7. Gedilaghine V. La rationalisation du traitement des mammites en exploitation laitière. Conception et réalisation d'une enquête d'évaluation de la mise en place de l'action G.T.V. Partenaire dans le département de la Manche. Thèse pour le doctorat vétérinaire, Maisons Alfort; 2005. $106 \mathrm{p}$.
8. Kadja MC. Etude des mammites subcliniques dans les élevages bovins laitiers en Afrique de l'Ouest, cas du Sénégal et du Bénin. Thèse de doctorat Université Cheikh Anta Diop de Dakar; 2010. 156p.

9. Harmon RJ. Physiology of mastitis and factors affecting somatic cell counts. J Dairy Sci. 1994;77(7):2103-2112.

10. M'Sadak Y, Mighri L Kraiem K. Etude de la situation sanitaire mammaire à partir des taux cellulaires de troupeau et estimation des pertes laitières engendrées chez des ateliers bovins hors sol en Tunisie. Nature and Technologie. 2010;4:08-14.

11. Soltys J, Swain SD, Sipes KM, et al. Isolation of bovine neutrophils with biomagnetic beads: comparison with standard Percoll density gradient isolation methods. J Immunol Methods. 1999;226(1-2):71-84.

12. Johansson I, Korkman N, Nelson NJ. Studies on udder evacuation in dairy cows I: The amount and composition of the residual milk after normal milkings. Acta Agr Scand. 1952;2:43-81.

13. Millogo V, Norell L, Ouédraogo GA, et al. Effect of different hand-milking techniques on milk production and teat treatment in Zebu dairy cattle. Trop Anim Health Prod. 2011;44(5):1017-1025.

14. Forsbäck L, Lindmark-Månsson $\mathrm{H}$, Andrén A, et al. Udder quarter milk composition at different levels of somatic cell count in cow composite milk. Animal. 2009;3(5):710-717.

15. Millogo V. Milk Production of Hand-Milked Dairy Cattle in Burkina Faso. Doctoral Thesis, Uppsala, Sweden; 2010:4. 